https://doi.org/10.4316/CC.2020.02.004

\title{
KEY EVENTS OF THE SECOND PERIOD OF THE ARMED CONFLICT IN THE EAST OF UKRAINE (05. 09. 2014 - 30. 04. 2018)
}

\author{
Mykhailo HREBENIUK , Valerii HRYTSIUK ID, \\ Pavlo SHCHYPANSKYI \\ The National Defence University of Ukraine, Kyiv (Ukraine), \\ E-mails: mykhailo.hrebeniuk@nuou.org.ua; skifwo@email.ua; \\ znunp@nuou.org.ua
}

\begin{abstract}
The article aims to structure the accumulated factual material about the Russian Federation's armed aggression against Ukraine, which began on 20 February 2014 and developed a historical periodization variant. The research's main result is that the authors prove that the Russian Federation's armed aggression caused the armed conflict in the East of Ukraine. The authors set out the actual course of the main events in chronological sequence and determined the Russian-Ukrainian armed confrontation's key milestones at the beginning of the 21st century. According to the nature of military operations, military-political results and the consequences of the armed conflict in the East of Ukraine, it is divided into periods within which stages are distinguished, qualitatively different in purpose, nature and content of combat (special) operations. To repulse and deter this aggression, Ukraine used the forces of the security and defence sector. The form of these forces employment from 14 April 2014 to 30 April 2018 was the Anti-Terrorist Operation, and after - the Joint Forces Operation. This military-historical study creates the basis for further scientific research on the study of the armed conflict in the East of Ukraine. Such research is necessary to have a clearer understanding of the nature and essence of Russia's hybrid war against Ukraine, a more in-depth analysis of its evolution, and broader dissemination of lessons learned in the course of countering hybrid threats in the military sphere.
\end{abstract}

Keywords: armed conflict, East of Ukraine, hybrid war, Russian Federation, Ukraine, armed aggression.

Rezumat. Principalele evenimente ale celei de-a doua perioade a conflictului armat din estul Ucrainei (05.09.2014 - 30.04.2018). Articolul își propune să structureze materialul acumulat privitor la agresiunea armată a Federației Ruse împotriva Ucrainei,

Copyright (C) 2020 “Codrul Cosminului”, XXVI, 2020, No. 2, p. 357-378. 
care a început la 20 februarie 2014, și să dezvolte o variantă a periodizării sale istorice. Principalul rezultat al cercetării este că autorii dovedesc că în estul Ucrainei conflictul armat a fost cauzat de agresiunea armată a Federației Ruse. Autorii au stabilit cursul evenimentelor principale în ordine cronologică și au determinat etapele cheie ale confruntării armate rusoucrainene la începutul secolului XXI. În funcție de natura operațiunilor militare, de rezultatele politico-militare și consecințele conflictului armat din estul Ucrainei, acest este împărțit în perioade, în cadrul cărora se disting etape, calitativ diferite ca scop, natură și conținut ale operațiunilor de luptă (speciale). Pentru a respinge și a descuraja această agresiune, Ucraina a folosit forțele din sectorul securității și al apărării. Forma de angajare a acestor forțe a fost Operațiunea Antiteroristă (din 14 aprilie 2014 până la 30 aprilie 2018), iar ulterior Operațiunea Forțelor Unite. Prezentul studiu militar-istoric creează premisele pentru dezvoltarea cercetărilor științifice privitoare la conflictul armat din estul Ucrainei. $O$ astfel de cercetare este necesară pentru a avea o înțelegere mai clară a naturii și esenței războiului hibrid al Rusiei împotriva Ucrainei, o analiză mai profundă a evoluției sale și o diseminare mai vastă a lecțiilor învățate în cursul contracarării amenințărilor hibride în sfera militară.

\section{INTRODUCTION}

The Russian Federation's armed aggression against Ukraine that began on 20 February 2014 and had a hybrid nature led to the occupation of Crimea and caused an armed conflict in the East of Ukraine. In the second issue of the "Codrul Cosminului" for 2018, the authors highlighted the first period of the armed conflict in the East of Ukraine. ${ }^{1}$ Then we promised to continue our study.

The article aims to offer the scientific community a variant of the armed conflict periodisation in the East of Ukraine, structure the accumulated factual material and create a basis for further scientific research on this phenomenon's study. It helps researchers build a clear understanding of the nature and essence of Russia's hybrid war against Ukraine, analyse its evolution, and generalise the lessons learned in the course of countering hybrid war in the military sphere.

A military historical analysis of Russian armed aggression anticipated a sequence of successive research stages. ${ }^{2}$ The knowledge building on a historical process begins with a chronological fixation of past events and their description.

\footnotetext{
${ }^{1}$ Mykhailo Hrebeniuk, Valerii Hrytsiuk, Oleksandr Skriabin, The Main Events of the First Period of Armed Conflict in the East of Ukraine (April - September 2014), in „Codrul Cosminului”, XXIV, 2018, No. 2, p. 377-408.

2 Владимир Бережинский, Методология и структура военно-исторического исследования [Methodology and structure of military-historical research], Київ, Видавець
} 
However, the chronology itself is purely descriptive because the task of carrying out a meaningful analysis of the considered phenomena and processes is not assumed at that stage. The chronologic description captures the events dispassionately in the flow of time, and it does not establish causal relationships and does not provide an assessment of historical trends and patterns. Nevertheless, relying on a reliable and complete historical chronicle of events related to the aggression of the Russian Federation, and applying a scientific methodology, one can not only find cause-effect relationships but also reveal the objective laws which stand behind these relationships and determine that they acquire new stable qualities, becoming the objective laws themselves.

\section{ARGUMENTATION}

Military historical science considers periodisation as one of the methods for studying military conflicts. It allows dividing wars and armed conflicts into specific time extents (periods, phases, stages), which qualitatively differ in military-political objectives, the nature and content of military operations. The boundaries of the period are determined by events that mark the turning points in military conflicts. Each period covers a certain number of military campaigns and operations. ${ }^{3}$ It is important to note that military operations are planned and conducted to achieve designed objectives. In turn, during military-historical research, the processes describing past events are usually considered in stages. ${ }^{4}$ In Ukrainian military-historical literature, the terms "phase" and "stage" are actively used for the historical processes' periodisation, in particular, to denote the substructural components of a period. ${ }^{5}$

Historians use different types of periodisation of military conflicts, especially, to distinguish between strategic and historical periodisation. Strategic pe-

Олег Філю, 2015, 64 с.; Василий Логин, Диалектика военно-исторического исследования [Dialectics of military-historical research], Москва, Наука, 1979, 169 с.; Иван Ковальченко. Методы исторического исследования [Methods of historical research], Москва, Наука, 2003, 486 с.

${ }^{3}$ Д. О. Рогозин (ред.), Война и мир в терминах и определениях [War and peace in terms and definitions], Москва, ПоРог, 2004, с. 77-78.

${ }^{4}$ Н. В. Огарков (ред.), Военный энциклопедический словарь [Military Encyclopedic Dictionary], Москва, Воениздат, 1983, с. 836.

${ }^{5}$ White Book of Antiterrorist Operation in the East of Ukraine in 2014-2016, Kyiv, Ministry of Defence of Ukraine, 2017, 162 p., in https://nuou.org.ua/assets/journals/ bila_knyga/white-book-ato.pdf (Accessed on 11.06.2020). 
riodisation is established during the planning of the war and is implemented during its development. This involves the breakdown of the war into several successive parts (campaigns), each solving specific problems through the employment of a particular array of military forces. Simultaneously, military historians use periodisation, which divides the war by actual progress according to the results achieved. Historical periodisation is determined by the sequence of actions, each of which has its name following its characteristic content. ${ }^{6}$

The periodisation of the Russian Federation's armed aggression against Ukraine, the armed conflict in the East of Ukraine and the anti-terrorist operation/the Joint Forces Operation have already become a subject to some studies ${ }^{7}$, diversified in terms of issues under consideration and form.

In the project developed by "Information Resistance" group and titled The Invasion of Ukraine. The Chronicle of Russian Aggression, the armed conflict events are presented through the authors' analysis of Russian aggression in 2014-2016, which is conditionally divided into 11 stages. Because the book appeals to a broad audience, the armed conflict periodisation is more popular than scientific. ${ }^{8}$

In his scientific work The War in the East of Ukraine: the first phase (1 March - 24 August 2014), Pavlo Guy-Nyzhnyk, a Ukrainian historian, divides the events of the Russian-Ukrainian armed conflict into five periods. Giving the names for the periods, the author uses the style of large-scale periodisation of big wars ("position war", "frail war"). Still, instead of using military terminology, he fails to avoid the use of literature cliches (like "Front without resistance", "Minsk trap", "Norman odds", etc.). ${ }^{9}$

6 Д. О. Рогозин (ред.), Война и мир в терминах и определениях, с. 77-78.

${ }^{7}$ András Rácz, Russia's Hybrid War in Ukraine. Breaking the Enemy's Ability to Resist. FIIA Report 43, Helsinki, The Finnish Institute of International Affairs, 2015; Artis Pabriks, Andis Kudors (eds.), The War in Ukraine: Lessons for Europe, Riga, The Centre for East European Policy Studies, 2015; Agnieszka Pikulicka-Wilczewska, Richard Sakwa (eds.), Ukraine and Russia. People, Politics, Propaganda and Perspectives, Bristol, E-International Relations, 2016; Michael E. Aleprete Jr., Minimizing Loss: Explaining Russian Policy Choices during the Ukrainian Crisis, in "The Soviet and Post-Soviet Review", Vol. 44, 2017, No. 1, p. 53-75; David R. Marples, Ukraine in Conflict. An Analytical Chronicle, Bristol, E-International Relations, 2017; etc.

${ }^{8}$ Вячеслав Гусаров, Юрий Карин, Константин Машовец, Дмитрий Тымчук, Вторжение в Украину: Хроника российской агрессии [Invasion of Ukraine: A Chronicle of Russian Aggression], Киев, Брайт Стар Паблишинг, 2016, 240 с.

9 Павло Гай-Нижник, Війна на Сході України: перша фаза (1 березня - 24 серпня 2014 p.) [The War in the East of Ukraine: the first phase (March 1 - August 24, 2014)], in Війна на Донбасі. 2014-2017 рр., зб. наук. праць за матеріалами III Всеукраїнської 
Volodymyr Vilk's work intituled Periodisation of the Russo-Ukrainian Hybrid War: 2014-2017, despite its stated name, defines only the so-called informationpsychological periodisation war of the Russian Federation against Ukraine in 2014-2015.10

The representative of Lviv Military History School, Doctor of Historical Sciences, Olesia Kutska divides the anti-terrorist operation into two periods within which the researcher allocates 14 stages "to identify and isolate indirect changes in studying the experience of using the Armed Forces and other paramilitary formations of Ukraine (emphasised by us because the term is not precise) within the framework of the anti-terrorist operation in 2014 - 2018."11 However, the researcher does not explain why there is the gap between the second (21. 05 06. 07. 2014) and third (07. 07. 2014) stages of the manoeuvring period (emphasised by us), and does not take into account that the beginning of active actions of the anti-terrorist operation forces accounts for 1 July 2014 - following the decision of the Supreme Commander of the Armed Forces of Ukraine. The place of the Debaltsevo operation (February 2015) in the periodisation remains unclear. The author indicates the date of completion of the ATO - 23. 02. 2018. In fact, a largescale anti-terrorist operation in some areas of Donetsk and Luhansk oblasts lasted from 14 April 2014 to 30 April 2018. On that last day, on the Presidential Decree, the format of the East of Ukraine's anti-terrorist operation was changed for the

наукової військово-історичної конференції (Київ, 19 квітня 2018 р.) [War in the Donbass. 2014-2017: From the materials of the II All-Ukrainian Scientific-Military-Historical Conference (Kyiv, April 19, 2018)], Київ, Національний військово-історичний музей України, 2018, с. 29-34.

10 Володимир Вилко, Періодизація російсько-української гібридної війни: 2014 - 2017 роки [Periodization of the Russian-Ukrainian Hybrid War: 2014 - 2017], in Війна на Донбасі. 2014-2016 рр.: зб. наук. праць за матеріалами II Всеукраїнської наукової військово-історичної конференції (Київ, 20 квітня 2017 р.) [War in the Donbass. 2014-2017: From the materials of the 2nd All-Ukrainian Scientific-Military-Historical Conference (Kyiv, April 19, 2018)], Київ, Національний військово-історичний музей України, 2018, с. 218-222.

11 Olesia Куцька, Антитерористична операція на Сході України (2014-2018 рр.): етапи та їх характеристика [Anti-terrorist operation in the East of Ukraine (20142018): stages and their characteristics], in Людина і техніка у визначних битвах світових воєн ХХ століття: збірник доповідей Міжнародної наук. конф. (Львів, 25-26 червня 2019 року) [Man and technology in the outstanding battles of the world wars of the 20th century: a collection of reports of International sciences. Conf. (Lviv, June 25-26, 2019)], Львів, Національна академія Сухопутних військ імені гетьмана Петра Сагайдачного, 2019, с. 16-18. 
Joint Forces Operation. ${ }^{12}$

The Scientific Centre for Military History of the Ivan Chernyakhovsky National Defence University of Ukraine worked out the scientific and journalistic publication White Paper of the Anti-Terrorist Operation in the East of Ukraine (20142016). The cooperative involvement of various structures of the security and defence sector made it possible to comprehensively explore the Ukrainian defence forces' role and place in counteracting the aggressor. The authors carried out a historical periodisation of the armed conflict in the East of Ukraine, dividing it into major periods and distinguishing the stages in them that are qualitatively different in purpose, nature and content of hostilities. The authors covered the actual course of the significant events in chronological order and highlighted the Russian-Ukrainian armed confrontation's key milestones at the beginning of the $21^{\text {st }}$ century. The periodisation was agreed by the General Staff of the Armed Forces of Ukraine and approved by the Minister of Defence of Ukraine. The book's English-language version was presented at the NATO-Ukraine Partnership and Collective Security Committee meeting held at Alliance Headquarters in November 2017. The White Book of the ATO materials, including the ATO historical periodisation, has been published with the NATO support and, on the authors' opinion, should be taken into account in the coverage of the events of the Eastern of Ukraine' armed conflict. ${ }^{13}$ However, this version of periodisation of the armed conflict in the East of Ukraine was not complete enough as it was limited by the events of 2016.

We expand and deepen these positions on the pages of "Codrul Cosminului". The previous publication The Main Events of the First Period of Armed Conflict in the East of Ukraine (April - September 2014) covered the main events of the first period of the armed conflict in the East of Ukraine. ${ }^{14}$

In this article, we call the second period of armed conflict in the East of

12 Про рішення Ради національної безпеки і оборони України від 30 квітня 2018 року "Про широкомасштабну антитерористичну операцію в Донецькій та Луганській областях": Указ Президента України від 30 квітня 2018 р. № 116/2018 [On the decision of the National Security and Defence Council of Ukraine of April 30, 2018 "On a large-scale anti-terrorist operation in Donetsk and Luhansk regions": Presidential Decree \# 116/2018 of April 30, 2018], in https://zakon.rada.gov.ua/laws/ show/116/2018 (Accessed on 11.06.2020).

${ }^{13}$ White Book of Antiterrorist Operation in the East of Ukraine in 2014-2016, Kyiv, Ministry of Defence of Ukraine, 2017, 162 p.

${ }^{14}$ Mykhailo Hrebeniuk, Valerii Hrytsiuk, Oleksandr Skriabin, The Main Events of the First Period of Armed Conflict in the East of Ukraine (April - September 2014), "Codrul Cosminului", XXIV, 2018, No. 2, pp. 377-408. 
Ukraine as "Conflict Localisation in Certain Districts of Donetsk and Luhansk Oblasts (5 September 2014 - 30 April 2018.)". We divided the second period into consequent stages, considering the existence of the three stages in the first period.

Stage Four. Stabilisation of the Confrontation Line in the East of Ukraine (5 September 2014 - 14 January 2015.)

Since early September 2014, at the fourth stage of the anti-terrorist operation in the Donetsk and Luhansk oblasts, ATO forces were to move onto the defensive due to Russian troops' invasion. This stage's characteristic feature was the beginning of large-scale construction of the defence barrier in the East of Ukraine, which started in September 2014. Two defence lines were created: the first one on the confrontation line with the Russian occupation troops, and the second one - at 15-20 km from it. Their basis was a system of strongholds with checkpoints, trenches, shelters, communication trenches, and firing positions of armoured combat vehicles and other firearms. ${ }^{15}$ As of the end of 2014, ATO forces performed the tasks of isolating the crisis area by covering positions and conducting defence at 94 checkpoints, three observation posts, 110 platoon strongpoints, 30 company strongpoints, and one battalion defence area.

Russian hybrid warfare occupation forces continuously committed acts of provocation aimed at stirring up the armed conflict. ${ }^{16}$ Thus, from 5 September 2014

\footnotetext{
${ }^{15}$ The authors believe that to name such hostile to Ukraine armed groups like "pro-Russian", "militias", "separatists" is not correct (although such a practice still exists). Politicians and military, scientists and the media in various countries cannot find the right terms to describe the occupation of Crimea and the armed aggression of the Russian Federation against Ukraine. These difficulties are not accidental but a result of hybrid warfare techniques. Seeking to create the illusion of a civil war in Ukraine, Moscow's political technologists tried to provoke the Ukrainian side and especially the international community to use distorted and ambiguous terminology to form misconceptions and negative attitudes of their society and state institutions towards the events in Ukraine. International security organizations (UN, PACE and others) have recognized the occupation of part of Ukraine by the Russian Federation. It is "occupation", not "annexation", "invasion" or something else.

After analysing a large array of documents and materials that reveal the quantitative and qualitative characteristics of the enemy group in the occupied territories of Ukraine, the authors introduce a new term: "Russian hybrid warfare occupation forces".

16 The Law of Ukraine "On Peculiarities of State Policy to Ensure State Sovereignty of Ukraine in the Temporarily Occupied Territories in Donetsk and Luhansk Oblasts" (Про особливості державної ... | від 18.01.2018 № 2268-VIII (rada.gov.ua)) confirms that the Russian Federation temporarily occupied part of the territory of Ukraine with the help of armed formations of the Russian Federation consisting of regular formations and units
} 
to 15 January 2015, Ukrainian troops were shelled 21250 times. ${ }^{17}$ Due to the enemy forces' insidiousness and the negligence of the Minsk agreements by the Russian leadership during the ceasefire, the armed confrontation in the East of Ukraine acquired the features of the protracted 'frozen' conflict. The so-called 'regular armed forces' of the 'DPR' and 'LPR' ('1st and 2nd Army Corps') were formed from the various illegal armed groups of Russian mercenaries and local collaborators, under the leadership of Russian cadre officers (see Figure No 1). The share of the local population in the mentioned units did not exceed 35\%. These forces were controlled and supported from the Russian Federation territory. ${ }^{18}$

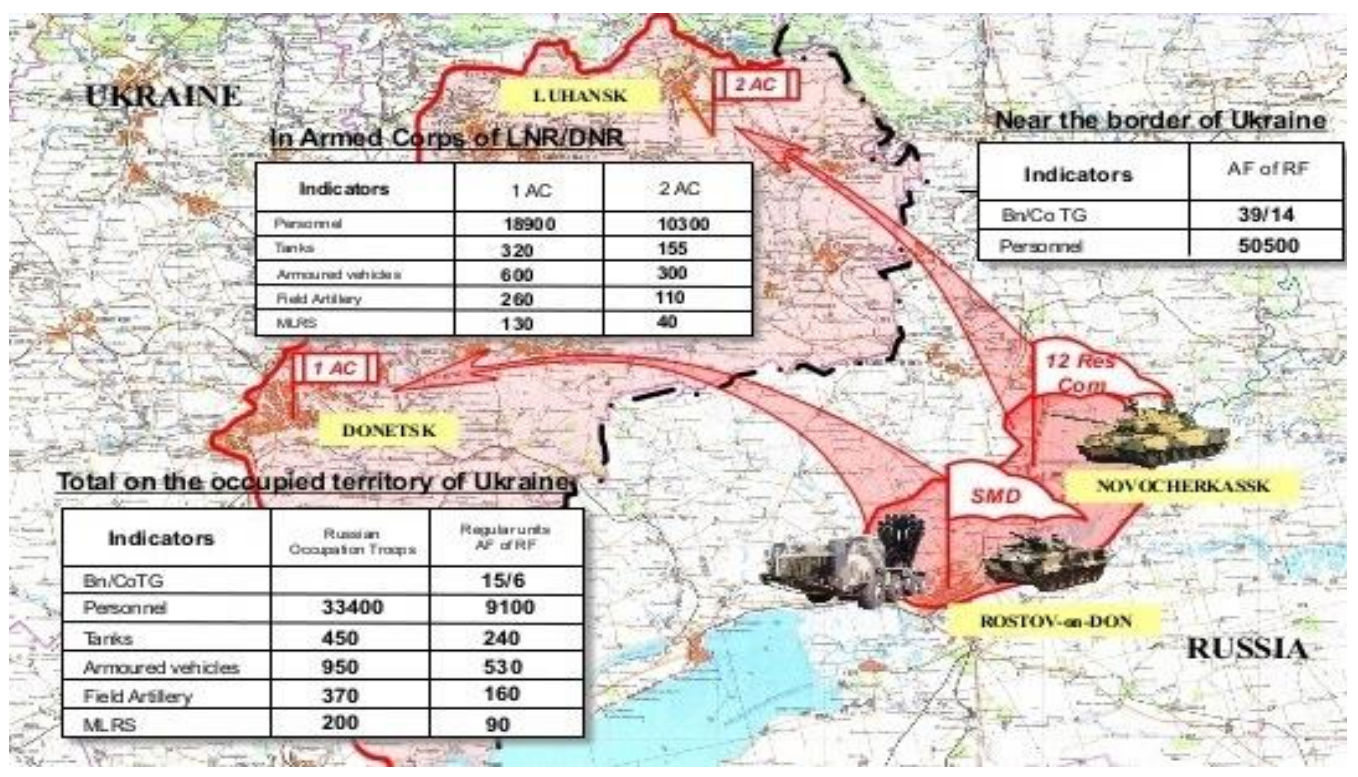

Figure No. 1. Total Strength of the $1^{\text {st }}$ and $2^{\text {nd }}$ Army Corps of DNR/LNR and Russian Troops on occupied territories near the southern border of Ukraine ${ }^{19}$

subordinated to the Ministry of Defence of the Russian Federation, units and special formations subordinated to other law enforcement agencies of the Russian Federation, their advisers, instructors and local collaborators, criminals, militants of irregular illegal armed formations, armed gangs, financial gangs and mercenary groups as well as with the help of the occupation administration of the Russian Federation. The latter is consisted of its state bodies and structures functionally responsible for the management of the temporarily occupied territories of Ukraine, and controlled by the Russian Federation governing bodies that perform power functions in the temporarily occupied territories of Ukraine. 17 White Book of Antiterrorist Operation in the East of Ukraine in 2014-2016, p. 34-35.

18 Ibid.

${ }^{19}$ Created by the authors and based on Збройна агресія Російської Федерації проти 
Stage Five. Repulse of the Second Offensive of the Russian Occupation Forces (15 January - 20 February 2015).

The winter of 2015 proved to be no less 'hot' than the summer of 2014. In January, the enemy began to implement a plan to expand the controlled territories, which involved simultaneous offensives in the Luhansk, Donetsk, Debaltseve, and Mariupol directions.

One of the 'hottest' places in the ATO was the Donetsk airport, which became a symbol of courage and heroism of Ukrainian fighters, whom the enemy called 'Ukrainian cyborgs'. It became a kind of 'pain in the neck' for Russian invaders. It is not a coincidence that elite Special Forces units of the Russian Armed Forces were involved in the seizure of this objective. The 242-day defence of the airport involved not only holding of the terminal buildings and the control tower. The fighting also continued for the control of Avdiivka, Pisky, Opytne, and Vodiane localities. The Ukrainian units' sustained defence at this sector of the confrontation line between the warring parties provided a reliable cover for the whole Donetsk direction. ${ }^{20}$

In the history of victories of the Ukrainian army, the days of January 2015 are filled with tragedy and sacrifice of Ukrainian soldiers. On 15 January, the enemy began the assault with artillery and mortar fire at the new Donetsk airport terminal. Exploiting fires' effects, the enemy assumed the offensive, seized part of the airport and blocked the Ukrainian paratrooper units in the 'new terminal'. Since the Russians blew up the terminal, the construction's main elements collapsed, burying its defenders. On 22 January, the last small group of Ukrainian fighters left the terminal ruins in which there were no longer any walls that could be defended.21

України. Інформаційно-довідковий матеріал [Armed aggression of the Russian Federation against Ukraine. Complementary material], Київ, Національний університет оборони України імені Івана Черняховського, 2015, 14 с., in https://mon.gov.ua/storage/app/media/zagalna\%20serednya/metodichni\%20 recomendazii/2019/06/materiali-inform-hromologia-2019.doc (Accessed on 11.06.2020).

${ }^{20}$ Аналіз бойових дій на сході Украӥни в ході зимової кампанії 2014-2015 років [Analysis of hostilities in eastern Ukraine during the 2014-2015 winter campaign], https://www.mil.gov.ua/news/2015/12/23/analiz-bojovih-dij-na-shodi-ukraini-vhodi-zimovoi-kampanii-2014\%E2\%80\%932015-rokiv--16785/ (Accessed on 11.06.2020)

${ }^{21}$ Біла книга-2015. Збройні Сили України [White Book-2015. The Armed Forces of Ukraine], p. 88-90, in https://upload.wikimedia.org/wikipedia/commons/1/1a/ WB_2015.pdf (Accessed on 11.06.2020). 
Late in January, Russia's hybrid occupation forces launched an offensive on the Debaltsevo bridgehead, trying to surround and destroy the Ukrainian troops located there. For this purpose, the enemy concentrated significant forces of the Russian Federation's regular troops and the most combat-ready illegal armed formations of self-proclaimed "republics" (see Figure No. 2). The strength of enemy troops reached 7-9 thousand people, supported by up to 120 tanks, 180 artillery systems, 60 multiple launch rocket systems. ${ }^{22}$

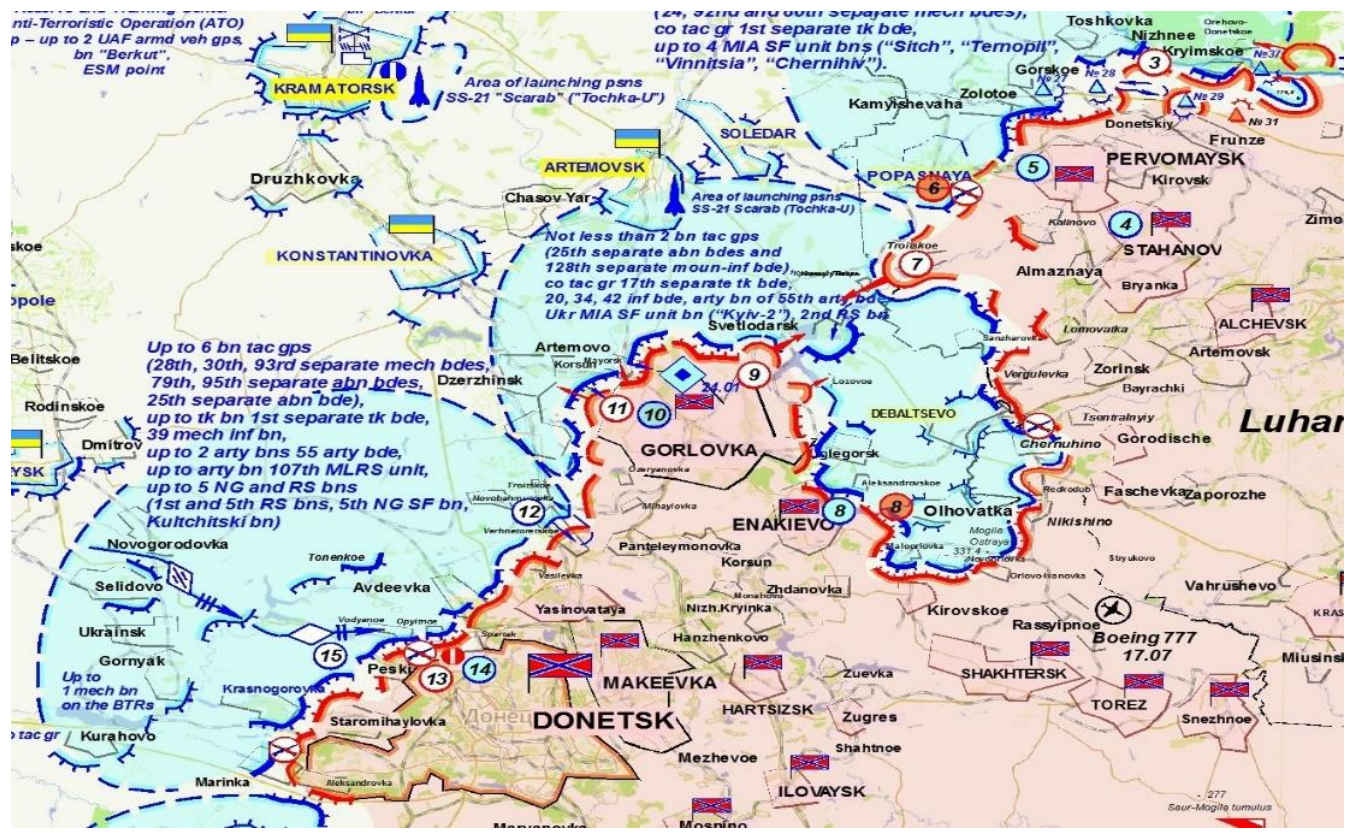

Figure No. 2. The Debaltseve Pocket ${ }^{23}$

The total number of personnel of the Armed Forces of Ukraine units, which performed tasks directly in the Debaltsevo bridgehead area in February 2015, amounted to about 4,7 thousand military personnel. About 500 people more were involved from the National Guard of Ukraine, the Ministry of Interior of Ukraine

22 Аналіз Генерального штабу ЗСУ щодо бойових дій на Дебальцівському плацдармі $з$ 27 січня до 18 лютого 2015 р. [Analysis of the General Staff of the Armed Forces of Ukraine as for the combat actions on Debaltsevo bridgehead from 27 January - 18 February 2015], in https://www.mil.gov.ua/analitichni-materiali/analiz-generalnogoshtabu-zsu-shhodo-bojovih-dij-na-debalczevskomu-placzdarmi-z-27-sichnya-do-18lyutogo-2015-roku.html (Accessed on 11.06.20).

${ }^{23}$ The Debaltseve Pocket, in https://bigtalksmalltalk.wordpress.com/2015/01/25/thedebaltseve-pocket/ (Accessed on 18.12.2020). 
and the Security Service of Ukraine. There were 50 tanks, 40 artillery systems, 15 multiple launch rocket systems at the disposal of Ukrainian troops in the Debaltsevo area. A significant advantage of the enemy in human resources and equipment became apparent. ${ }^{24}$

Fighting under the direct threat of encirclement, 2678 defenders of the 'Debaltsevo offset' held the line. The ATO command conducted an action to withdraw them from the area under enemy attacks. To uphold the taking out of the Ukrainian forces the operational order of battle was built with a system of areas, lines and positions, and mobile armoured groups (as reserves) in the rear. As a result of the Debaltsevo manoeuvre, the aggressor's plans were frustrated. Debaltsevo defenders showed the examples of tenacity and endurance. 2629 soldiers exited the encirclement. ${ }^{25}$ Ukrainian troops managed to keep the barrier line on the Luganka River and gain a foothold on Luhanske, Troyitske, and Popasna. The losses suffered forced the enemy to abandon further offensives.

With the completion of the Debaltsevo operation (27 January - 18 February 2015), a shaky truce began in Donbas. The results of the winter campaign greatly influenced the further development of the military-political and military-strategic environment. During the operations, the Ukrainian troops accomplished all their tasks, were withdrawn from the enemy strikes to new areas with minimal losses and took the advantageous operational position. The adversary advance into the depth of the territory of Ukraine was stopped.

Following the results of lengthy negotiations on 15 February 2015, a joint declaration was adopted by the Presidents of Ukraine, the French Republic, the Russian Federation and the Chancellor of the Federal Republic of Germany to support the package of measures for the legal implementation of the Minsk agreements. According to this document, the ceasefire regime was to come into effect, and from 24 February the withdrawal of heavy weapons from the contact line was to begin. ${ }^{26}$

However, the aggressor insidiously violated these agreements, like the previous ones. In 2015 alone, starting on 15 February, ATO forces were fired at more than 16,4 thousand times; 205 armed clashes took place. The Ukrainian units opened fire in response to the enemy's provocative actions mainly during armed clashes, providing the information to the leadership of the OSCE Special Monitoring Mission accordingly. ${ }^{27}$

\footnotetext{
24 Ibid.

${ }^{25}$ Біла книга-2015. Збройні Сили України, р. 90.

26 White Book of Antiterrorist Operation in the East of Ukraine in 2014-2016, p. 36-37.

${ }^{27}$ Біла книга-2015. Збройні Сили Украӥни, р. 13.
} 
The sixth stage. Strengthening the Defence Line in Eastern Ukraine (21 February 2015 - 20 September 2016)

In order to provide the militaries with favourable conditions for conducting defence operations, the first task was to establish a line of defence in the East of Ukraine, equipped with powerful fortifications. The efforts and resources from all regions of Ukraine were involved in this task.

After the second offensive of the Russian occupation forces was repulsed in January - February 2015, the construction of a fortified defence line in the eastern regions has become the priority goal of Ukraine. In the spring and summer of 2015, 20 regions of Ukraine contributed to the construction of a fortified line of defence in the ATO area. The total volume of building materials used in the construction course was 35 thousand railway cars, 12 thousand concrete structures were installed in the ATO area. Three defensive lines were erected, at which about 300 strongpoints were equipped and connected by $600 \mathrm{~km}$ of fortifications. ${ }^{28}$ The Armed Forces units and detachments occupied the first line of defence, and the objects of the second and the third lines were taken under the protection of the National Guard units.

The construction and improvement of the defence line in Eastern Ukraine continued throughout 2015 and after. Due to the construction of protective structures, the number of military casualties was reduced.

Thus, through joint efforts of the grouping of forces and means of the anti-terrorist operation, the authorities of state executive power and local self-government, fortified defence belts were built.

The construction of the defence line in the East of Ukraine became a significant step towards improving the Ukrainian territory's protection system. Consolidated fortifications increase personnel's security and create better conditions for military units and detachments to perform combat missions. The experience of warfare has shown the utmost importance of the fortification equipment of checkpoints, strongholds, base camps and control points to ensure the maintenance of life of personnel and skilful cover by engineering barriers to prevent sudden attacks by illegal armed groups.

Simultaneously with the creation of the defensive zone, a high level of professionalism was acquired by Ukrainian servicemen. In the second anti-terrorist

${ }^{28} 600$ км фортифікацій і 300 оборонних споруд. Зубко відзвітував про лінію оборони на Донбасі [600 km of fortifications and 300 strongpoints. Zubko reported on the line of defense in Donbas] in http://www.slovoidilo.ua/2015/07/21/novyna/bezpeka/ 600-km-fortyfikaczij-i-300-oboronnyx-sporud.-zubko-vidzvituvav-pro-liniyu-oborony-na-donbasi (Accessed on 22.12.20) 
operation period (05.09.2014 - 30.04.2018), the sector's forces' primary efforts were focused on stabilising the confrontation line, repelling attacks by Russian occupying troops, preventing the displacement of anti-terrorist operation forces from occupied strongholds and bypassing them. Defence actions of tactical groupings were planned and carried out.

A demonstrative example of troops' employment in military operations was the defensive battle of the 2nd Battalion Tactical Group of the 28th Separate Mechanized Brigade near Marinka in summer 2015. This locality in the outskirts of Donetsk was always a fighting ground. On 3 June, intensive artillery and "Grad" MLRS salvos were fired at ATO forces' positions. The enemy tried to break through the Ukrainian defences in a narrow area, where considerable infantry and armour forces were sent. Tank units supported the assault. To avoid devastating fire, Ukrainian defenders had to abandon some positions. ATO forces used artillery units to repel the enemy's offensive and thus the opponent's advance was stopped. (see Figure No. 3). The enemy retreated towards Donetsk. ${ }^{29}$

Since 2015, a system of military-civilian administrations was established and operated in the area of anti-terrorist operation as temporary state authorities in Donetsk and Luhansk regions' territory. They became part of the Anti-Terrorist Centre under the Security Service of Ukraine.

A civil-military cooperation system was introduced in the Armed Forces of Ukraine to prevent social tension in the area of anti-terrorist operation. The civilian population was supported by military and non-military personnel and assets in addressing their vital issues. These activities made it possible to minimise the effects of hostilities on civilians and enhance the ability to counter the negative Russian information influence on the population in the state.

In the face of significant threats to national security, Ukraine was forced to take several measures to localise the conflict in some districts of Donetsk and Luhansk regions. In particular, in cooperation with other entities of the nationwide counter-terrorism system, the Security Service of Ukraine introduced and monitored the movement of persons, vehicles and goods across the confrontation line within the Donetsk and Luhansk regions.

In 2016-2018, the Russian Federation's hybrid war against Ukraine continued, and the force component remained an essential means of achieving its political goals. The Russian Federation's leadership sought to form a militant group in the occupied territory of Donbas that would pose a significant military threat to

${ }^{29}$ Серж Марко, Хроника гибридной войны [Chronicle of the hybrid war], Київ, Альтерпpec, 2016, c. 139-140. 
Ukraine in the eastern region. Numerous facts of issuing Russian passports to Ukrainian citizens living in the occupied territories reinforce Russian aggression's hybrid nature. ${ }^{30}$

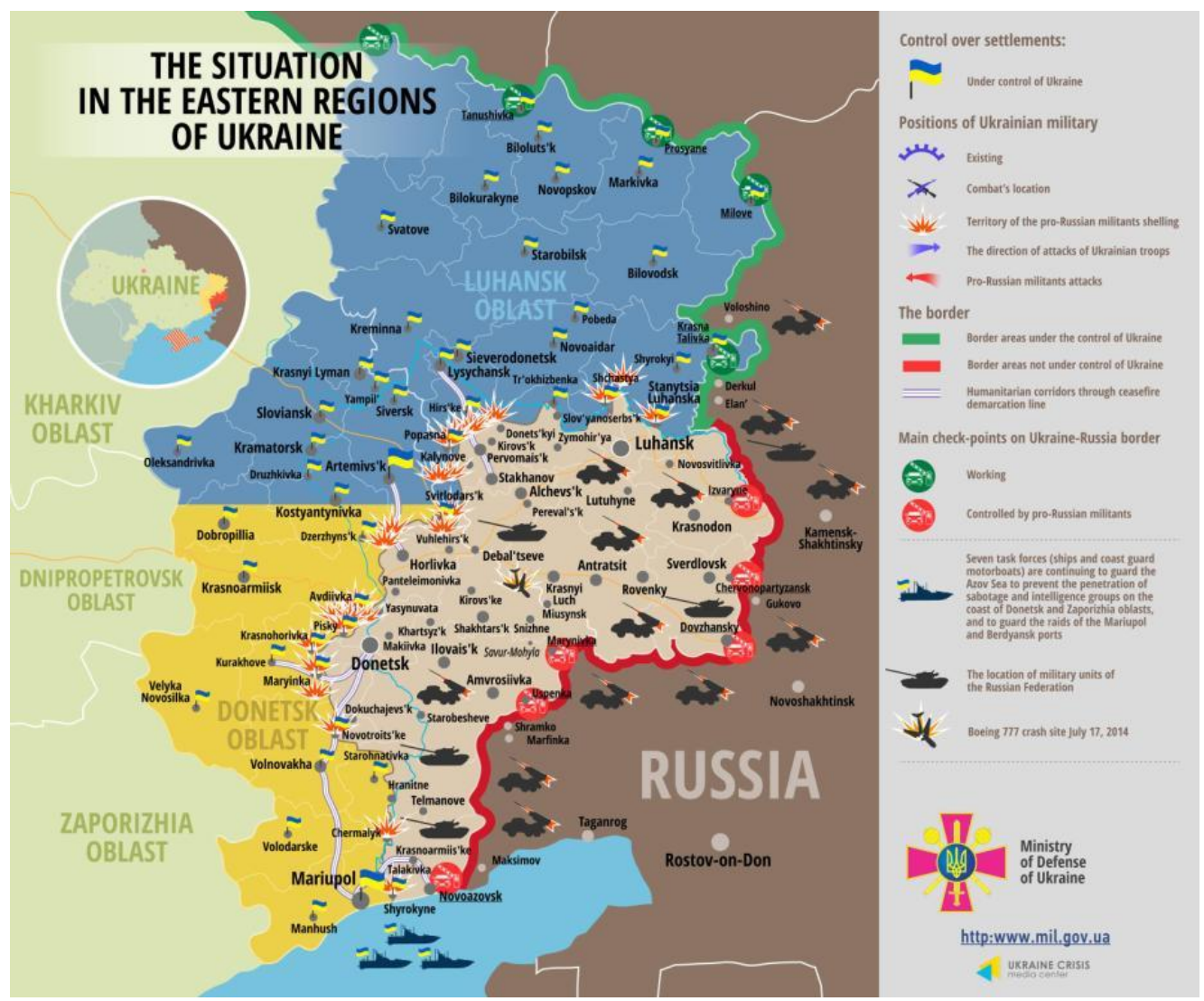

Figure No. 3. The situation in the Eastern Regions of Ukraine in September 2015 (from the daily official report on MOD website) ${ }^{31}$

Russian military units with a total number of about 6,5 thousand troops remained in some areas of Donetsk and Luhansk regions. In parallel, the Russian Federation tried to make maximum use of local collaborators and foreign (mainly Russian) mercenaries to confront the Ukrainian power structures in the Donbas.

30 Alice Underwood, Citizenship without Borders: Russian Passports for Ukrainian Citizens, in https://www.wilsoncenter.org/blog-post/citizenship-without-borders-russianpassports-for-ukrainian-citizens (Accessed on 20.12.20).

31 The situation in the eastern regions of Ukraine as for 14 September 2015, in https://www.ukrinform.net/rubric-polytics/1884162-situation_in_ukraines_eastern_ regions_map_334324.html (Accessed on 18.12.20). 
Taking into account the forces and means of the so-called "1st and 2nd Army Corps", Russian occupation troops in the Donbas in the first half of 2016 reached the strength of almost 43000 pax, more than 700 tanks and 1330 combat armoured vehicles, nearly 750 pieces of artillery systems. ${ }^{32}$

In the context of a particular limitation of hostilities, Russia intensified the activities of special services, undercover agents, terrorist and sabotage groups in some areas of Donetsk and Lugansk regions, and the adjacent areas of Ukraine. It increased the number of outreach and other activities aimed at destabilising the East of Ukraine's situation.

The forms and techniques of employment of Russian hybrid occupation forces in 2016-2018 changed significantly compared to 2014-2015. Having abandoned active offensive actions, the Russian troupes in the Donbas switched to tactics of "harassing" activities, the purpose of which was to exhaust and demoralise the ATO forces. The enemy tried to provoke the soldiers of the Armed Forces of Ukraine to an active response in order to accuse Ukraine of violating the Minsk agreements. As part of this tactic, the enemy typically resorted to shelling ATO forces, laying mines on roads and bridges and launching armed attacks by sabotage and reconnaissance groups. ${ }^{33}$

The seventh stage. Separation of forces and military equipment of warring parties (21 September 2016 - November 2017).

Since September 2016, the nature of the Russian-Ukrainian confrontation in the East of Ukraine changed significantly, mainly due to the Tripartite Contact Group decision, and to the signing on 21 September 2016 in Minsk on the separation of forces and assets of belligerent parties in the Donbas. The document provided for the withdrawal of troops by both sides from the positions they had occupied in both directions for the formation of $2 \mathrm{~km}$ wide and $2 \mathrm{~km}$ deep sections. ${ }^{34}$

The Russian occupation forces continued to violate the agreement, did not

32 Аналітична доповідь до Щорічного Послання Президента України до Верховної Ради України "Про внутрішнє та зовнішнє становище України в 2016 році" [Analytical Report to the Annual Message of the President of Ukraine to the Verkhovna Rada of Ukraine "On Internal and External Situation of Ukraine in 2016"], Київ, НІСД, 2016, c. 33., in https://niss.gov.ua/sites/default/files/2016-10/poslanya_new-cc2e3.pdf (Accessed on 12.06.20).

${ }^{33}$ Біла книга-2017. Збройні Сили України [White Book 2017. Armed Forces of Ukraine], Міністерство оборони України, 2018, с. 16., in https://www.mil.gov.ua/content/ files/whitebook/WB-2017.pdf (Accessed on 12.06.20).

${ }^{34}$ White Book of Antiterrorist Operation in the East of Ukraine in 2014-2016, p. 38. 
comply with the "ceasefire". Throughout 2016-2019, the enemy focused on moving their units deeper into the no-man's-land called the "grey zone", while actively shelling Ukrainian troops' positions and observing the tactics of "waging a war of attrition". The use of snipers, sabotage and reconnaissance groups, artillery and mortar shelling of Ukrainian defenders' positions in the Lugansk, Donetsk, Mariupol directions acquired a systemic character. Adversary maintained constant pressure in the settlements of Krymskoe, Novotoshkovskoe, Zolotoe, Zhelobok, and Svetlodarsk Novoselovka, Avdeevka, Maryinka, Novomikhailovka, Starognatovka, Vodyanoye, Shirokino.

A significant event in 2016 was the fighting on the Svitlodar Arc. On 17-18 December, Russian hybrid occupation forces attempted to break through the line of defence and seize Ukrainian troops' positions by launching a surprise artillery attack at them. In these conditions, the Ukrainian defenders sustained, and then proceeded to active action and pushed the enemy from their positions south of the Luhanske village. From 19 December to 22 December 2016, the Russian hybrid occupation forces tried to regain their positions and fired at Ukrainian units from all weapons types. Still, they were not able to force the Ukrainian defenders to abandon their posts. On 23 December, the Ukrainian military units entered the village of Novoluhanske, which had remained in the "grey zone" for a long time. ${ }^{35}$

In the fighting in Svitlodar Arc, the Ukrainian troops successfully applied the tactics of "frog jumps", gradually taking up new positions and forcing the enemy to retreat. From the first days of January 2017, the anti-terrorist operation forces in the Svitlodar Arc exploited success. They occupied several major facilities that made the possibility to reduce the number of enemy shellings in the area and the risks of having units enveloped by the enemy. On 19 January, that situation enabled the Ukrainian troops to approach Vuglehirsk and Debaltseve which had to be controlled by Ukrainian side according to the Minsk Agreements.

At the end of 2016, the situation in the Donetsk area escalated. Avdiivka, located near Donetsk, Yasinovataya and Gorlivka was in the epicentre of attention. Avdiivka remained under the control of Ukraine according to the Minsk Agreements from 2014 until 2015. However, the Russian command brutally violated the signed agreements both in this area and throughout the front. The concept of the "Avdiivka industrial zone" became a symbol of severe fighting. As a result of a complex of effective actions, the Ukrainian Armed Forces units significantly improved their tactical situation without violating the Minsk agreements. During 2017-2018, Avdiivka

35 Ibid., p. 39. 
remained one of the hottest spots in the armed conflict zone. ${ }^{36}$

Thus, the seventh stage is characterised by the separation of forces and equipment of the warring parties, in accordance with the results of the Tripartite Contact Group decision. Simultaneously, throughout the perimeter of the armed conflict, the enemy was concentrating its efforts on advancing its units deep into the "grey zone". The most intense fighting took place in Svitlodar Arc (December 2016). The Ukrainian forces repelled the Russian occupation forces, exploited success and improved their tactical situation in the Avdiivka industrial zone (December 2016 - January 2017). ${ }^{37}$

At that time, the troops' main efforts were focused on stabilising the line of contact between the parts, repelling the attacks of the Russian occupation troops and preventing the displacement of anti-terrorist operation forces from occupied strong points and bypassing them. The defensive operations of tactical groups were planned and carried out.

The eighth stage. The improvement of troops command and control system. Completion of the anti-terrorist operation (November 2017 - April 2018).

It should be noted that Ukraine's confrontation with Russian aggression in 2014-2017 showed that the anti-terrorist operation, as a form of opposition to attack, had already gone beyond its intended purpose and had a military-defensive character. At the end of 2017 - beginning of 2018, the current challenge was to update the legal framework of using defence forces to protect the state from the Russian Federation's armed aggression.

On 24 February 2018, the Law of Ukraine "On Features of State Policy for ensuring state sovereignty of Ukraine in temporarily occupied territories in Donetsk and Luhansk regions" came into force and changed the previous format of the anti-terrorist operation and the procedure of using the Armed Forces of Ukraine, other military formations and law enforcement authorities. Therefore, the legal framework was created to launch the Joint Forces operation to ensure national security and defence, to repel and deter armed aggression in the Donetsk

${ }^{36}$ Біла книга-2017. Збройні Сили України, с. 16.

${ }^{37}$ Що сталося в Авдіївці? [What happened in Avdiivka], “Дзеркало тижня”, № 4, 4 лютого

- 10 лютого 2017 p., in http://gazeta.dt.ua/internal/scho-stalosya-v-avdiyivci-_.html (Accessed on 22.12.20); Хронологія загострення ситуації в районі н. п. Авдіївка 29 січня 2017 року [Chronology of exacerbation of the situation in vicinity of Avdiivka 29 January 2017]/Генеральний штаб ЗСУ, 3 лютого 2017 p. [General Staff of the Armed Forces of Ukraine, 3 February 2017] in https://www.facebook.com/ GeneralStaff.ua/posts/732453826923877 (Accessed on 22.12.20). 
and Luhansk regions. ${ }^{38}$

On 30 April 2018, the President of Ukraine signed a decree "On approval of the decision of the Council of National Security and Defence On a large-scale antiterrorist operation in Donetsk and Luhansk regions". The same day, he (the President of Ukraine), as Supreme Commander-in-Chief of the Armed Forces of Ukraine, signed the order "On the commencement of the Joint Forces operation to ensure national security and defence, to repel and deter the armed aggression of the Russian Federation in Donetsk and Luhansk regions". According to the order from 2:00 p.m. on 30 April 2018, the Joint Force Operation began. ${ }^{39}$

Therefore, the second period of the armed conflict in the East of Ukraine can be regarded as a positional one, that is characterised by the transition to predominantly defensive operations, the requirements for the withdrawal of heavy weapons by both sides from the delimitation line and the creation of security zones; stable holding of designated areas, boundaries and positions by the anti-terrorist operation forces; slow advancing of our units into the depth of the territory and taking under the control of certain localities of the so-called "grey zone"; constant violations of the Minsk Agreements by the Russian side, shelling of positions of Ukrainian troops by the Russian occupation forces and its adherence to the tactics of "war on exhaustion".

The proposed periodisation of the armed conflict in the East of Ukraine has been tested on international and all-Ukrainian scientific conferences ${ }^{40}$.

38 Про внесення змін до деяких законів України щодо визначення дати початку тимчасової окупації: Закон України від 15 вересня 2015 р. № 685-VIII [On Amendments to the Laws of Ukraine on Determining the Date of Temporary Occupation Commencement: Law of Ukraine of September 15, 2015 \# 685-VIII], Відомості Верховної Ради України, 2015, № 46 (13.11.2015), Ст. 417, in https://zakon.rada.gov.ua/laws/ show/685-19 (Accessed on 12.06.20).

39 Про рішення Ради національної безпеки і оборони України від 30 квітня 2018 року "Про широкомасштабну антитерористичну операцію в Донецькій та Луганській областях": Указ Президента України від 30 квітня 2018 р. № 116/2018 [On the decision of the National Security and Defence Council of Ukraine of April 30, 2018 "On a large-scale anti-terrorist operation in Donetsk and Luhansk regions": Presidential Decree \# 116/2018 of April 30, 2018], Ст. 174, in https://zakon.rada.gov.ua/ laws/show/116/2018 (Accessed on 11.06.20).

40 В. М. Грицюк, О. Л. Скрябін, Періодизація збройного конфлікту на Сході України [Periodization of the Armed Conflict in the East of Ukraine], Програма Всеукраїнської науково-практичної конференції "Роль і місце національної спецслужби в історії українського державотворення (Київ, 17 березня 2017 р.)” [Program of the AllUkrainian Scientific and Practical Conference "The Role and Place of National Special 


\section{CONCLUSIONS}

The Russian Federation's armed aggression against Ukraine and occupation of the part of her territory testified that the application of the forces was mainly a departure from the traditional forms and methods of warfare and had elements of a hybrid nature. The Russian Federation's armed aggression initially led to the occupation of the Crimea and subsequently to an armed conflict in the East of Ukraine. To counteract and deter this aggression, Ukraine has deployed the security and defence sector forces. The form of employment of the security and defence forces from the 14 April 2014 was the Anti-Terrorist Operation, and from 30 April 2018, it is the Joint Forces Operation. In our opinion, the "Donbas War" is rightly classified as an armed conflict in the East of Ukraine, supported externally.

By the nature of the warfare, military and political results and consequences, the armed conflict in Eastern Ukraine is divided into three periods. Within these periods, the stages are distinguished qualitatively in the nature and content of the warfare.

Along with this, many aspects of the ATO still need to be thoroughly researched by military scientists and representatives of various fields of knowledge. In particular, the conceptual categorical apparatus associated with the Russian Federation's aggression against Ukraine, given its specific "hybrid" nature, still needs further clarification and improvement in the scientific works of researchers of this problem. In general, a comprehensive study of the armed conflict in the East of Ukraine is necessary to have a clear understanding of the nature of Russia's hybrid war against Ukraine, to analyse the evolution of the conflict and, ultimately, to summarise the experience of counteracting hybrid threats in the military sphere.

The events of 2014-2018 were the most severe exam for the existence of the Ukrainian state. In this tumultuous time of trials, military personnel of the Armed Forces of Ukraine, other military formations, representatives of law enforcement and volunteer formations displayed personal courage and heroism in defence of the state sovereignty and territorial integrity of Ukraine, selfless service to the Ukrainian people.

Service in the History of Ukrainian Statecraft (Kyiv, March 17, 2017)”], Київ, Служба безпеки України, Київський національний університет імені Тараса Шевченка, 2017, c. 18., in http://science.univ.kiev.ua/sbu.pdf (Accessed on 12.02.20). 


\section{BIBLIOGRAPHY:}

1. Aleprete Jr. Michael E., Minimizing Loss: Explaining Russian Policy Choices during the Ukrainian Crisis, in "The Soviet and Post-Soviet Review", Vol. 44, 2017, No. 1, p. 53-75.

2. Hrebeniuk M., Hrytsiuk V., Skriabin O., The Main Events of the First Period of Armed Conflict in the East of Ukraine (April - September 2014), in "Codrul Cosminului", XXIV, 2018, No. 2, p. 377-408.

3. Marples David R., Ukraine in Conflict. An Analytical Chronicle, Bristol, E-International Relations, 2017.

4. Pabriks Artis, Kudors Andis (eds.), The War in Ukraine: Lessons for Europe, Riga, The Centre for East European Policy Studies, 2015.

5. Pikulicka-Wilczewska Agnieszka, Sakwa Richard (eds.), Ukraine and Russia. People, Politics, Propaganda and Perspectives, Bristol, E-International Relations, 2016.

6. Rácz András, Russia's Hybrid War in Ukraine. Breaking the Enemy's Ability to Resist. FIIA Report 43, Helsinki, The Finnish Institute of International Affairs, 2015.

7. The Debaltseve Pocket, https://bigtalksmalltalk.wordpress.com/2015/01/25/ the-debaltseve-pocket/\#_ftn1

8. Underwood Alice, Citizenship without Borders: Russian Passports for Ukrainian Citizens, in https://www.wilsoncenter.org/blog-post/citizenship-without-bordersrussian-passports-for-ukrainian-citizens

9. White Book of Antiterrorist Operation in the East of Ukraine in 2014-2016, Kyiv, Ministry of Defence of Ukraine, 2017, https://nuou.org.ua/assets/journals/ bila_knyga/white-book-ato.pdf

10. 600 км фортифікацій і 300 оборонних споруд. Зубко відзвітував про лінію оборони на Донбасі $[600 \mathrm{~km}$ of fortifications and 300 strongpoints. Zubko reported on the line of defense in Donbas], http://www.slovoidilo.ua/2015/07/21/novyna/ bezpeka/600-km-fortyfikaczij-i-300-oboronnyx-sporud.-zubko-vidzvituvav-pro-liniyuoborony-na-donbasi

11. Аналіз бойових дій на сході України в ході зимової кампанії 2014-2015 років [Analysis of hostilities in eastern Ukraine during the 2014-2015 winter campaign], https://www.mil.gov.ua/news/2015/12/23/analiz-bojovih-dij-na-shodi-ukraini-v-hodizimovoi-kampanii-2014\%E2\%80\%932015-rokiv--16785/

12. Аналіз Генерального штабу ЗСу щодо бойових дій на Дебальцівському плацдармі з 27 січня до 18 лютого 2015 р. [Analysis of the General Staff of the Armed Forces of Ukraine as for the combat actions on Debaltsevo bridgehead from 27 January - 18 February 2015], https://www.mil.gov.ua/analitichni-materiali/analiz-generalnogoshtabu-zsu-shhodo-bojovih-dij-na-debalczevskomu-placzdarmi-z-27-sichnya-do-18lyutogo-2015-roku.html

13. Аналітична доповідь до Щорічного Послання Президента України до Верховної Ради України "Про внутрішнє та зовнішнє становище України в 2016 році" [Analytical Report to the Annual Message of the President of Ukraine to the Verkhovna 
Rada of Ukraine "On Internal and External Situation of Ukraine in 2016"], Київ, НІСД, 2016, https://niss.gov.ua/sites/default/files/2016-10/poslanya_new-cc2e3.pdf

14. Бережинский В., Методология и структура военно-исторического исследования [Methodology and structure of military-historical research], Київ, Видавець Олег Філю, 2015.

15. Біла книга-2015. Збройні Сили України [White Book-2015. The Armed Forces of Ukraine], https://upload.wikimedia.org/wikipedia/commons/1/1a/WB_2015.pdf

16. Біла книга-2017. Збройні Сили України [White Book 2017. Armed Forces of Ukraine], Міністерство оборони України, 2018, https://www.mil.gov.ua/content/ files/whitebook/WB-2017.pdf

17. Вилко В., Періодизація російсько-української гібридної війни: 2014 - 2017 роки [Periodization of the Russian-Ukrainian Hybrid War: 2014 - 2017], іn Війна на Донбасі. 2014-2016 рр.: зб. наук. праць за матеріалами II Всеукраїнської наукової військово-історичної конференції (Київ, 20 квітня 2017 р.) [War in the Donbass. 2014-2017: From the materials of the II All-Ukrainian Scientific-Military-Historical Conference (Kyiv, April 19, 2018)], Київ, Національний військово-історичний музей України, 2018, с. 218-222.

18. Гай-Нижник П., Війна на Сході України: перша фаза (1 березня - 24 серпня 2014 p.) [War in the East of Ukraine: the first phase (March 1 - August 24, 2014)], in Війна на Донбасі. 2014-2017 рр., зб. наук. праць за матеріалами ІІІ Всеукраїнської наукової військово-історичної конференції (Київ, 19 квітня 2018 р.) [War in the Donbass. 20142017: From the materials of the II All-Ukrainian Scientific-Military-Historical Conference (Kyiv, April 19, 2018)], Київ, Національний військово-історичний музей України, 2018, c. 29-34.

19. Генеральний штаб ЗСУ, Хронологія загострення ситуації в районі н. n. Авдіївка 29 січня 2017 року [Chronology of exacerbation of the situation in vicinity of Avdiivka 29 January 2017], 3 лютого 2017 р [3 February 2017], https://www.facebook.com/ GeneralStaff.ua/posts/732453826923877

20. Грицюк В.М., Скрябін О.Л., Періодизація збройного конфлікту на Сході України [Periodization of the Armed Conflict in the East of Ukraine], Програма Всеукраїнської науково-практичної конференції "Роль і місце національної спецслужби в історії українського державотворення. (Київ, 17 березня 2017 р.)” [Program of the AllUkrainian Scientific- and Practical Conference "The Role and Place of National Special Service in the History of Ukrainian State-Craft. (Kyiv, March 17, 2017)”], Київ, Служба безпеки України, Київський національний університет імені Тараса Шевченка, 2017, c. 18., http://science.univ.kiev.ua/sbu.pdf

21. Гусаров В., Карин Ю., Машовец К., Тымчук Д., Вторжение в Украину: Хроника российской агрессии [Invasion of Ukraine: A Chronicle of Russian Aggression], Киев, Брайт Стар Паблишинг, 2016.

22. Збройна агресія Російської Федерації проти України. Інформаційно-довідковий матеріал [Armed aggression of the Russian Federation against Ukraine. Complementary material], Київ, Національний університет оборони України імені Івана Черняховського, 2015, https://mon.gov.ua/storage/app/media/zagalna\%20 
serednya/metodichni\%20recomendazii/2019/06/materiali-inform-hromologia2019.doc

23. Ковальченко И., Методы исторического исследования [Methods of historical research], Москва, Наука, 2003.

24. Куцька Олеся, Антитерористична операція на Сході України (2014-2018рр.): етапи та їх характеристика [Anti-terrorist operation in the East of Ukraine (20142018): stages and their characteristics], in Людина і техніка у визначних битвах світових воєн ХХ століття : збірник доповідей Міжнародної наук. конф. (Львів, 25-26 червня 2019 року) [Man and technology in the outstanding battles of the world wars of the XX century: a collection of reports of International Scientific Conference (Lviv, June 25-26, 2019)], Львів, Національна академія Сухопутних військ імені гетьмана Петра Сагайдачного, 2019, с. 16-18.

25. Логин В., Диалектика военно-исторического исследования [Dialectics of military-historical research], Москва, Наука, 1979.

26. Марко Серж, Хроника гибридной войны [Chronicle of the hybrid war], Київ, Альтерпрес, 2016.

27. Огарков Н. В. (ред.), Военный энциклопедический словарь [Military Encyclopedic Dictionary], Москва, Воениздат, 1983.

28. Про внесення змін до деяких законів України щодо визначення дати початку тимчасової окупації: Закон України від 15 вересня 2015 р. № 685-VIII [On Amendments to the Laws of Ukraine on Determining the Date of Temporary Occupation Commencement: Law of Ukraine of September 15, 2015 \# 685-VIII], Відомості Верховної Ради України, 2015, № 46 (13.11.2015), Ст. 417, https://zakon.rada.gov.ua/ laws/show/685-19

29. Про рішення Ради національної безпеки і оборони України від 30 квітня 2018 року "Про широкомасштабну антитерористичну операцію в Донецькій та Луганській областях": Указ Президента України від 30 квітня 2018 р. № 116/2018 [On the decision of the National Security and Defence Council of Ukraine of April 30, 2018 "On a large-scale anti-terrorist operation in Donetsk and Luhansk regions": Presidential Decree \# 116/2018 of April 30, 2018], https://zakon.rada.gov.ua/laws/show/116/2018

30. Рогозин Д. О. (ред.), Война и мир в терминах и определениях [War and peace in terms and definitions], Москва, ПоРог, 2004.

31. Що сталося в Авдіївці? [What happened in Avdiivka], “Дзеркало тижня”, № 4, 4 лютого - 10 лютого 2017 p., in http://gazeta.dt.ua/internal/scho-stalosya-v-avdiyivci.html (Accessed on 22.12.20) 